\title{
Pollutions - Social Responsibility and Green Banks as a Driver for Sustainable Development in Ukraine, on the Example of Privatbank
}

\author{
Ianina Tkachenko ${ }^{*}$ and Liudmyla Huliaieva ${ }^{\dagger}$ \\ * $\mathrm{PhD}$ (Economic Sciences), The Head of Finance Chair of The Academy of \\ Labor, Social Relations and Tourism (ALSRT) \\ ${ }^{\dagger} \mathrm{PhD}$ (Economic Sciences), Scientific Secretary, Associate Professor of the \\ Finance Chair of the Economics Department of The Academy of Labor, Social \\ Relations and Tourism (ALSRT)
}

\section{Introduction}

One of the biggest domestic banks in Ukraine is interviewed within the research. Established in 1992, PrivatBank became a state-owned company (Statute 2018). This is the bank that owns $42.27 \%$ of assets, $32.72 \%$ of capital and $39.61 \%$ of credit and investment portfolios of the banking system the of Ukraine, as of 1 October 2016. According to market research carried out by Gfk Ukraine in the fourth quarter of 2015, 40.2\% of individual clients considered PrivatBank to be their main bank. Privat is also the leader in the sphere of financial services for corporate clients. Thus, the share of corporate customers who use the services of Privatbank, is $42.6 \%$.

The Bank's network in Ukraine comprises the following (PrivatBank 2016):

- 2.5 thousand branches

• 7200 ATMs

How to cite this book chapter:

Tkachenko, I. and Huliaieva, L. 2019. Pollutions - Social Responsibility and Green Banks as a Driver for Sustainable Development in Ukraine, on the Example of Privatbank. In: Gąsior, A. (ed.) Pro-ecological Restructuring of Companies: Case Studies, Pp. 159-169. London: Ubiquity Press. DOI: https://doi.org/10.5334/bbk.n. License: CC-BY 4.0 
- 12,500 self-service terminal (SSTs)

- 1400 postamats

Overestimating importance of PrivatBank as that of an employer in the Ukrainian labour market would be difficult. More than 35,000 people are employed in this bank. PrivatBank is a socially responsible bank and employs people with disabilities ( $4 \%$ of the total workforce). Furthermore, PrivatBank offers a full social-benefits package, a paid annual vacation of 24 calendar days, a concession-lending system, participation in the private pension fund programme, and travel vouchers at discounted prices for adults and children. PrivatBank has been recognized as an innovator in the Ukrainian market and worldwide. Thi is despite the relatively low level of the financial market of Ukraine in comparison with European countries and the crisis situation in the banking system of Ukraine (in 2014-2016 84 insolvent banks were removed from the market; that is $45.6 \%$ of their total number).

According to NACE classification (KVED 2016) PrivatBank is universal bank and provides banking services to the population and legal entities; payment, depository services, equity account, securities brokerage and other banking services with the transition from servicing in bank branches to training of customers for application of remote banking instruments.

\section{Company and Restructuring}

The bank represents the quaternary sector of the economy. In general, the process of pro-ecological restructuring is very useful for a deposit corporation because it brings a lot of positive transformations to the bank, namely increasing the bank's clients, because of the innovative bank service with the transition from servicing in bank branches to training of customers in the application of remote banking instruments, operative cost reducing, increased profitability and so on.

The decision to enact pro-ecological restructuring in this deposit corporation was made by a manager of the company. The main reasons for it were the changes in technology, the need to improve the financial situation of the company and the qualitative changes.

PrivatBank has already achieved some objectives in this sphere, among which are improvement of organization, financial restructuring, ecological restructuring and employment restructuring. When discussing the socio-economical aspect, we should define the gained benefits: customer and local community loyalty, boost to the reputation and increased market share. Everything mentioned above was achieved by business planning, current asset optimization, program of development, corporate and social responsibility realization, optimization of operative process and implementation of strategies for social responsibility.

Detailed company information is given in Table 1 . 


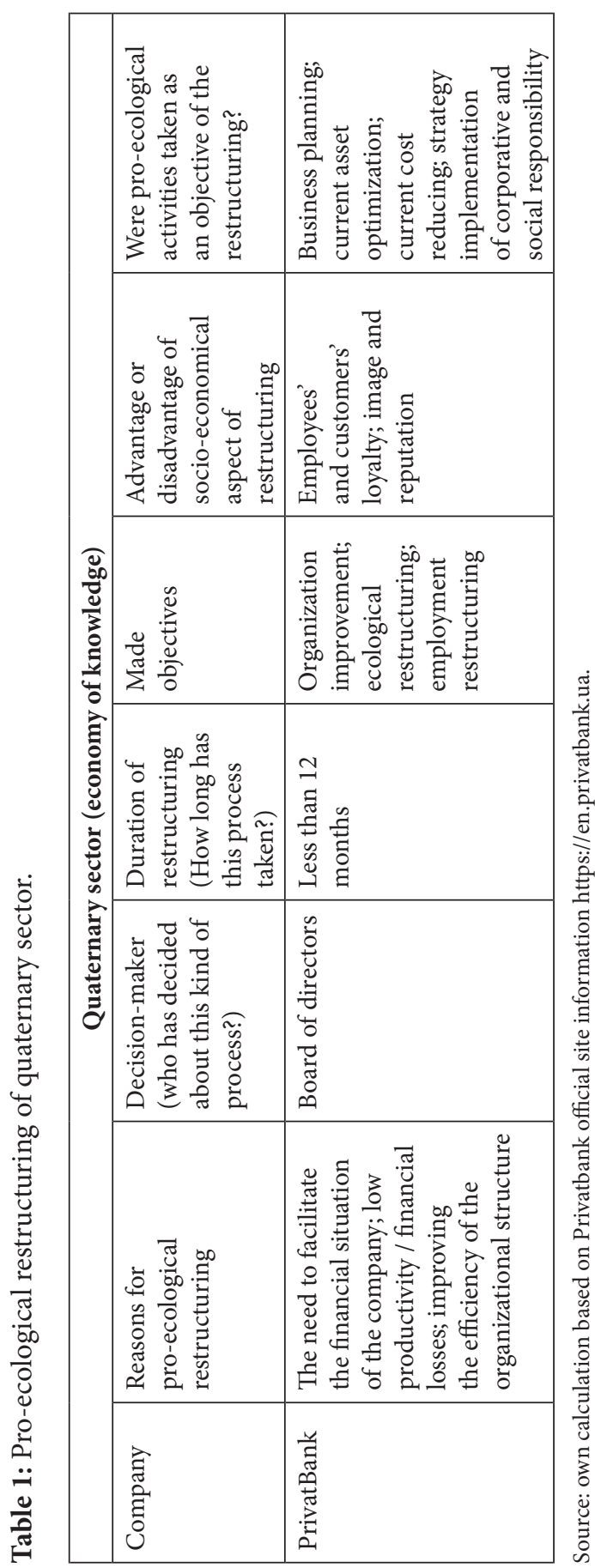


PrivatBank is the leading banks in Ukraine in the implementation of environmental initiatives, focusing on the strategy development for the "green bank" model. The first step in this direction was the implementation of the practice of a "green office" in all divisions of the bank across the country. In a fairly short time, all documentation was transferred from the paper bank to the electronic one. The environmental technology cash collection was introduced into the bank. It is important to point out that the bank not only introduces environmental component to its business model, but also strongly promotes environmental and social responsibility of its corporate and private clients. PrivatBank promotes the emergence of new environmental trends in Ukrainian society, through numerous environmental and social orientation projects:

- The "green office". In 2016, thanks to the work of electronic document management systems and the electronic banking systems of PrivatBank, the bank employees and its customers have saved more than 473 tons of paper, which means a saving of 13.5 hectares of forest. Also, PrivatBank annually saves more than 20 tons of paper by introducing electronic services providing information and a digital system for processing incoming correspondence - letters and requests of customers. On admission to the bank, all external correspondence is transferred into electronic form, and the majority of responses to customer requests are provided by email or ATMs and bank terminals.

- The introduction of new technologies in banking leads to reduction in the use of material resources as well as accelerates the "greening" of the real economy.

PrivatBank is one of the most high-tech world banks. "SMS-banking" (1999), OTP passwords via SMS (2000), P2P, transfers between cards (2003), "Electronic rest" (2009), "Online -inkasatsiya" (2010) and others are among the technologies that PrivatBank has been first to implement in the world. PrivatBank has become one of the first banks to implement a contactless technology for customer service via QR codes. Using QR, PrivatBank customers can log into their online bank accounts to withdraw cash from ATMs, to fill the car at the gas station, as well as make orders and pay at restaurants using their cell phones. Nowadays every third client of the bank enjoys its services via the Internet and mobile applications.

Ukrainian Privatbank, which is among the leading innovative banks in the world, has become one of the heroes of the digital banking guru Chris Skinner's new book, Value Web (Skinner 2016). As Skinner says, financial markets are reassessing their business models now. While not everybody has understood yet what is happening, the banks' visionaries who are integrators, aggregators and creators of banking services, divided into components, have appeared in the world. A good example of this is PrivatBank in Ukraine. Skinner belives that the PrivatBank team showes how innovative a modern bank can be. PrivatBank has opened API and created a 
transparent IT architecture, which easily interacts with external developers. Moreover, the author calls PrivatBank one of the first banks in the world to offer services on the API base and hundreds of different APIs, on which base, as with blocks.

Ukrainian PrivatBank was one of the first in the world to establish commercial mass production of robots allowing companies and entrepreneurs to maintain communication with customers and sell products via smartphone without cost supporting of mobile applications and platforms. Over 205 thousand corporate clients of PrivatBank and 450 thousand entrepreneurs receive free robots in Privat24 Sender, which are ready to communicate with customers and accept payment by bank cards.

Users of iPhone Privat 24 are the first in the world who are able to transfer money and fill in a mobile phone's account directly to their contact on iMessage, without needing to run applications and fill in the receiver's card number.

Privat 24 became the first in the world with an iOs payment plan that uses new possibilities of the iPhone and iMessage messenger base, realized in the tenth version of the Apple OS. As communicated in PrivatBank, the updated version of Privat24 allows the owners of iPhone to make exchanges between them directly through Messenger. All payment transactions and services, including service ordering are available from computer or a smartphone using the Privat24 Internet banking system.

Implementation of new technologies gives concrete positive results in reducing the negative impact of people on the environment. Active usage of Internet Banking "Private 24" by customers, as well as mobile banking and massive response of customers to the bank's appeals to refuse the print paper check.

The PrivatBank gives Ukrainian business the opportunity for free usage of effective the electronic document management system "PryvatDok", which motivates (due to effective tools) customers to move to the "green offices" operating model. This modern and secure service allows any private company or public company to give up paper documents, reduce costs and increase business efficiency. The system of electronic document flow is a "cloud" technology that does not require the customer's bank expenses for the development of IT infrastructure.

Another innovative environmental initiative in the business process of the bank is an environmental project of recycling of lead seals. As a result of environmental monitoring of work conducted by specialists of Privatbank, it was found that used lead seals often fall in the waste, which could lead to further risk of contamination of soil and groundwater. Now, lead seals that are used by the bank in the process of cash collection are collected and directly transferred to recycling.

- The implementation of sustainable environmental initiatives in local communities. The systematic action of cleaning up the environment, with active involvement of employees and bank customers as well as local communities, 
is held. Banking units, along with local communities, hold "green" Saturdays all over Ukraine to make the country cleaner through their efforts. Bankers, bank clients and partners clean parks, gardens, promenades and recreational areas through joint efforts. For example, in 2015, the bank's initiative was supported by more than 150 thousand caring people from 1360 cities of Ukraine. Following the "green" initiative of the bank, 500 thousand hectares of urban parks and recreation areas were cleaned, 1500 tons of garbage were removed and nearly 20 hectares of forest were planted. Moreover, large enterprises, including hundreds of Ukrainian companies, government agencies, factories and football clubs spend their Saturdays together with the bank.

Another pilot project is the establishing of Ukraine's largest network of bike parking by PrivatBank. Nowadays there are more than 400 bike parkings near the bank branches, and clients of offices can comfortably park their bikes in large cities and in rural areas.

Travel by bicycle in the city is a fashionable trend and saves fuel, but in the Ukrainian villages, biking is one of the main means of transportation.

- Educational activities amongst Ukrainians on resource conservation and eco-technologies.

The PrivatBank has now launched a new educational project, "Saving together!" through which customers of the bank and all the people of Ukraine are able to share their experiences and tips on how to conserve energy and other resources, as well as effective usage of resources and favorable choice of banking services. As a result of such a project, the folk encyclopaedia of economic activity is planning to be created.

The project aims at encouraging people to consolidate and help each other in the difficult economic situation in Ukraine. At a special site of the project, everybody can share how to save on food, clothing, entertainment or household items. Site users can not only read, but also evaluate each benefit of advice and vote for it. The expert group of PrivatBank will select the best advice and give monthly prizes to authors.

- The implementation of sustainable environmental initiatives in the business system of customers. Privatbank launched kub.pb.ua - a service of national lending for Ukrainian businesses, which is expected to be a powerful investment platform for implementation. The service allows small business and entrepreneurs to involve money for its development from individuals and companies and let the residents of the country invest money in Ukrainian business. The project aims at helping entrepreneurs in Ukraine, giving small business and the population the opportunity to receive loans quickly and transparently. It should become a powerful impetus for the development of small businesses and self-employment in Ukraine, for the revival of the credit market and for increasing the number of jobs in the country, particularly in environmental initiatives and social entrepreneurship. Entrepreneurs and businesses (restaurants, bakeries, shoe shops, photo studios, clothing 
stores etc.) interested in attracting investments will receive funding up to 300 thousand UAH at the site, and the application not only presents the business and plans for its development, but also offers additional bonuses and discounts for future investors. The online application "kub" will be active within two weeks: if the project collects the required amount, it will be recalculated to the owner of the company as the paid loan.

To best protect investments, the leading specialists of the bank hold a careful selection of projects for funding, based primarily on the characteristics of the current business and prospects of its development, rather than on collateral. To ensure protection, all attachments are also insured.

Within the new project, the incomes of investors will be higher than the deposits offered by bank, through direct investment in a business without the mediation of the financial institution. Investments can be counted from any bank card, and $25 \%$ of annual income will be paid monthly to the card. The PrivatBank, as the organizer of the platform, undertakes to relend the borrower in case he faces difficulties in loan repayment to investor, so the investor definitely gets their money back. Also, all loans in the "kub", and investments respectively will be fully insured by the insurance company.

The kub.pb.ua platform operates within the national program of small business development "Country of entrepreneurs", initiated by PrivatBank. This project will help everybody who wishes to start a business, and will help businesses to enjoy free advice and assistance.

- Increased transparency of the bank and its clients motivation to openness. Ukraine's largest bank, PrivatBank, was recognized as a leader in a rating of bank openness compiled by the Ukrainian credit rating agency (UCRA, 2015). It is worth mentioning the bank site, which is not only an important source of information where clients can get all the information about the bank and its services, but also an interactive channel of communication through which you can book a card deposit, make a transfer and use many other services with just a few clicks. In addition, PrivatBank's site is one of the most popular Ukraine Internet resources among the search engines and social networks.

- Charitable and social projects aimed at solving urgent problems in Ukrainian society. The bank takes an active social position, annually introducing dozens of measures of different scale and direction, including aid to soldiers of the antiterrorist operations, care and development of children, and help for temporarily displaced persons. Thus, PrivatBank became a partner of the international non-governmental organization GOAL under the new program of financial support for people affected by the conflict in Eastern Ukraine. Cash benefits are the most common form of humanitarian aid, protecting the life and dignity of people affected by crises, while ensuring that humanitarian aid is being used effectively. 
In 2015 PrivatBank was recognized as the best among major benefactors of Ukrainian companies in the framework of the national competition "Charitable Ukraine". PrivatBank finances not only a large number of charitable projects, but actively engages the community in the bank's projects, forming new socially responsible trends in society. In particular, in 2015320,000 citizens of Ukraine and around the world supported charitable projects organized by PrivatBank. To ensure transparency in the collection and control of expenditure of funds, a special blago.pb.ua has been created, which describes all the results of charitable programs that PrivatBank and its customers actively participate in.

For charitable projects, Privatbank has created its own charitable foundation, "It's Easy to Help", which regularly assists orphanages and boarding schools, children with cancer, as well as victims of natural disasters or terrorist attacks. The purpose of the fund is charitable activities on the behalf of public, individual groups, categories of persons who need care and protection; providing moral, material and financial support to individuals and legal entities; and promotion of education and culture. For this purpose, media enterprises, institutions, organizations, communities and Ukrainian diaspora are involved. Customers and employees of PrivatBank have collected over $\$ 52,240,000$ for charitable projects over five years (which is quite a noticeable amount of money for Ukraine).

An important factor in the success of charitable projects is the convenience and transparency of payments, so anyone can make a donation for any amount via PrivatBank, ATM or Internet banking through Privat 24 . The uniqueness of the fund and the program "It's Easy to Help!" is due to large investments of individual patrons or enterprises and through active involvement of society in solving social problems by the help of small amounts given by citizens. All people who transfer money will get a report on its use in e-mail or SMS.

The innovative character is embodied not only in the business processes of the bank, but also actively implemented primarily in the environmental and social responsibility of the bank. PrivatBank was the first Ukrainian bank to receive the Social Responsibility Mark award, assigned to the most socially responsible companies.

\section{Pro-ecological Aspects of Undertaken Restructuring Procceses}

This part investigates the factors of encouraging pro-ecological restructuring related to ecology and other issues (e.g. corporate social responsibility, stakeholders opinion, employment). Restructuring is mostly expressed in CSR implementation. Investigation also reveals the reason for it and shows the role and position of stakeholders in the process. The data is collected in following tables. 
Table 2: Undertaken restructuring process of quarterly sector.

\begin{tabular}{|c|l|l|l|}
\hline $\begin{array}{c}\text { Name of the } \\
\text { company }\end{array}$ & $\begin{array}{c}\text { Factors of great } \\
\text { influence on the } \\
\text { company and their } \\
\text { realization }\end{array}$ & $\begin{array}{c}\text { Reason for } \\
\text { implementation of } \\
\text { the CSR (corporate } \\
\text { and social } \\
\text { responsibility) }\end{array}$ & $\begin{array}{c}\text { Stakeholders and } \\
\text { restructuring }\end{array}$ \\
\hline PrivatBank & $\begin{array}{l}\text { 1) Political: } \\
\text { International trade, tax } \\
\text { policy, legal restriction; } \\
\text { 2) Economic: consumer } \\
\text { confidence, the } \\
\text { bankruptcy of a large } \\
\text { number of banks, rate } \\
\text { of inflation, exchange } \\
\text { rate; 3) Social: work, } \\
\text { education, demography, } \\
\text { income distribution; } 4) \\
\text { Technological: Internet, } \\
\text { development of } \\
\text { information technology }\end{array}$ & $\begin{array}{l}\text { New clients } \\
\text { involvement, } \\
\text { competitiveness, } \\
\text { higher motivation of } \\
\text { employees }\end{array}$ & $\begin{array}{l}\text { There is a } \\
\text { responsible } \\
\text { coordinator for } \\
\text { realization of the } \\
\text { CSR (board of } \\
\text { directors) }\end{array}$ \\
\hline
\end{tabular}

Source: own calculation based on Privatbank official site information https://en.privatbank.ua.

Tertiary and quarterly sectors are represented by PrivatBank. That is why the following factors (see Table 2) have the most visible effect. The reason for implementation of the SCR is, first of all, reputation, and so the deposit corporation struggles for value increasing and involving new clients.

To summarise all shown above, there are similar methods of restructuring in all sectors. Restructuring is mostly caused by the need to improve efficiency or competitiveness. The companies use the same instrument, and usually there is someone responsible for making restructuring and reacting to environmental turbulence.

\section{Pro-ecological Employment}

In this section, the purpose of our analysis is to determine the impact of undertaken ecological restructuring on employment in the company. All the processes related to the restructuring of the company have a huge impact on employment; of course, this also applies to ecological restructuring as well. Restructuring in this case includes the creation of new jobs (so-called green jobs) and modification of existing jobs in accordance with the new environmental standards, but often these processes lead to a reduction in staff. So it is quite natural that the attitude of workers towards the process of restructuring of the company cannot always be positive. Detailed company information about peculiarities of impact of pro-ecological restructuring on the employment are given below in Table 3. 
Table 3: Pro-ecological employment of quaternary sector.

\begin{tabular}{|l|l|l|}
\hline Creation of ecological/green jobs & Direct Activities & No \\
\cline { 2 - 2 } & Indirect Activities & Yes \\
Modification of work places & $\begin{array}{l}\text { Yes } \\
\text { No }\end{array}$ \\
\hline \multicolumn{2}{|l|}{ Existence of plans to create green jobs } & 0 \\
\hline Percentage of dismissed workers & 0.55 \\
\hline $\begin{array}{l}\text { Reaction of the staff to the } \\
\text { restructuring process }\end{array}$ & Supporting & 0.05 \\
\cline { 2 - 2 } & Against & $\begin{array}{l}0.4 \\
\text { Clients are interested in } \\
\text { this process } \\
\text { low level of involvement, } \\
\text { workers were only } \\
\text { informed about what was } \\
\text { happening; workers forced } \\
\text { to obey the processes }\end{array}$ \\
\hline Involvement of local communities in the processes of \\
\cline { 2 - 2 } ecological restructuring
\end{tabular}

Source: own calculation based on Privatbank official site information https://en.privatbank.ua.

So the importance of ecological restructuring for sectors of economy depends on their market specialization and the chosen direction of corporate development. Almost all banks paid careful attention to professional training according to the implementation of the ecological restructuring. PrivatBank (apparently in order to save resources) didn't create new jobs (green jobs) and tried to train staff and upgrade and modify already existing workplaces for new ecological standards.

PrivatBank, due to their specialization, considers the problems of ecological restructuring to be very important for development of the bank. PrivatBank plans to create divisions related to environmental protection to implement some aspects of environmental management. That is why the company considers professional training according to the implementation of the ecological restructuring to be highly important.

The study shows that in Ukraine, ecological restructuring in the bank sector is at a sufficient level.

\section{Summary of the Case Study}

Thus, pro-ecological restructuring for a job is modern trend for sustainable development. It brings plenty of advantages to the companies that have implemented the process as well as to the whole economy. Generally, the most sufficient benefits are: 
- saving the sources resulted in cost-cutting and

- growing reputation.

In the case of Ukraine, pro-ecological restructuring is considered and analysed according to the bank sector of the economy.

Quaternary sectors recognize the importance of pro-ecological restructuring and have made some sufficient steps in this direction. Basically, companies specialise in providing service, and that's why the main achieved objectives related to operating activity improvement, namely organization improvement, financial restructuring and employment restructuring. In terms of the socioeconomical aspect, gained advantages include: program of development, boost to the reputation, optimization of operative process, $R \& D$ department functioning, introduction of waste management, current asset optimization and increased market share.

There are ecological divisions created regarding new standards for the implementation of ecological restructuring. Modification of workplaces and special divisions related to environmental protection are also planned.

Due to the specialization of the quaternary sector, the problems of ecological restructuring aren't so important when comparing both primary and secondary sectors. Restructuring appears in professional training according to the implementation of the ecological restructuration.

\section{References}

KVED, Класифікатор видів економічної діяльності Available at https:// kved.biz.ua

PrivatBank https://en.privatbank.ua [Last accessed 21 December 2016]

PrivatBank Official site. Available at https://en.privatbank.ua/individuals/ branch-network/ [Last accessed 21 December, 2016]

Skinner, C 2016 ValueWeb: How Fintech Firms are Using Bitcoin Blockchain and Mobile Technologies to Create the Internet of Value. Published by Marshall Cavendish Business, Singapore.

Statute 2018, Статут акціонерного товариства комерційного банку Приватбанк.Нова редакція. 2018 Available at https://static.privatbank. ua/files/statut-new.PDF [Last accessed 21 August, 2018]

UCRA 2015, UCRA: исследование информационной прозрачности банков по результатам 2014 года Available at http:// https://news.finance.ua/ru/ news/-/346060/ucra-issledovanie-informatsionnoj-prozrachnosti-bankovpo-rezultatam-2014-goda 
